\title{
Soil organic carbon stabilization mechanisms and temperature sensitivity in old terraced soils
}

\author{
Pengzhi Zhao ${ }^{1}$, Daniel Joseph Fallu ${ }^{2}$, Sara Cucchiaro ${ }^{3,4}$, Paolo Tarolli ${ }^{4}$, Clive Waddington ${ }^{5}$, David Cockcroft ${ }^{5}$, \\ Lisa Snape $^{6}$, Andreas Lang ${ }^{6}$, Sebastian Doetterl ${ }^{7}$, Antony G. Brown ${ }^{2,8}$, and Kristof Van Oost ${ }^{1}$ \\ ${ }^{1}$ Georges Lemaître Centre for Earth and Climate Research, Earth and Life Institute, UCLouvain, \\ 1348 Louvain-la-Neuve, Belgium \\ ${ }^{2}$ Troms $\varnothing$ University Museum, UiT The Arctic University of Norway, Kvaløyen 30, 9013 Troms $\varnothing$, Norway \\ ${ }^{3}$ Department of Agricultural, Food, Environmental and Animal Sciences, University of Udine, \\ Via delle Scienze 206, 33100 Udine, Italy \\ ${ }^{4}$ Department of Land, Environment, Agriculture and Forestry, University of Padova, \\ Viale dell'Università 16, 35020 Legnaro, Italy \\ ${ }^{5}$ Archaeological Research Services Ltd, Angel House, Portland Square, Bakewell DE45 1HB, UK \\ ${ }^{6}$ Department of Geography and Geology, University of Salzburg, 5020 Salzburg, Austria \\ ${ }^{7}$ Department of Environmental Systems Science, ETH Zurich, Universitätstrasse 16, 8092 Zürich, Switzerland \\ ${ }^{8}$ Geography and Environmental Science, University of Southampton, Highfield, Southampton SO17 1BJ, UK
}

Correspondence: Pengzhi Zhao (pengzhi.zhao@uclouvain.be)

Received: 30 July 2021 - Discussion started: 24 August 2021

Revised: 23 October 2021 - Accepted: 8 November 2021 - Published: 8 December 2021

\begin{abstract}
Being the most common human-created landforms, terrace construction has resulted in an extensive perturbation of the land surface. However, our mechanistic understanding of soil organic carbon (SOC) (de-)stabilization mechanisms and the persistence of SOC stored in terraced soils is far from complete. Here we explored the factors controlling SOC stability and the temperature sensitivity $\left(Q_{10}\right)$ of abandoned prehistoric agricultural terrace soils in NE England using soil fractionation and temperature-sensitive incubation combined with terrace soil burial-age measurements. Results showed that although buried terrace soils contained 1.7 times more unprotected SOC (i.e., coarse particulate organic carbon) than non-terraced soils at comparable soil depths, a significantly lower potential soil respiration was observed relative to a control (non-terraced) profile. This suggests that the burial of former topsoil due to terracing provided a mechanism for stabilizing SOC. Furthermore, we observed a shift in SOC fraction composition from particulate organic $\mathrm{C}$ towards mineral-protected $\mathrm{C}$ with increasing burial age. This clear shift to more processed recalcitrant SOC with soil burial age also contributes to SOC stability in terraced soils. Temperature sensitivity incubations revealed that the
\end{abstract}

dominant controls on $Q_{10}$ depend on the terrace soil burial age. At relatively younger ages of soil burial, the reduction in substrate availability due to SOC mineral protection with aging attenuates the intrinsic $Q_{10}$ of SOC decomposition. However, as terrace soil becomes older, SOC stocks in deep buried horizons are characterized by a higher temperature sensitivity, potentially resulting from the poor SOC quality (i.e., soil $\mathrm{C}: \mathrm{N}$ ratio). In conclusion, terracing in our study site has stabilized SOC as a result of soil burial during terrace construction. The depth-age patterns of $Q_{10}$ and SOC fraction composition of terraced soils observed in our study site differ from those seen in non-terraced soils, and this has implications when assessing the effects of climate warming and terrace abandonment on the terrestrial $C$ cycle.

\section{Introduction}

Since post-Neolithic times, the construction of terraces has played an important role in the expansion and intensification of agriculture for food production (Brown et al., 2021). Terracing is recognized as a major adaptive strategy for land use 
in hilly areas and as an efficient conservation practice that provides multiple ecosystem services, e.g., erosion control and enhanced biomass yields, soil water recharge, and nutrient storage (Dunjó et al., 2003; Tarolli et al., 2014, 2015; Wei et al., 2016). At the same time the construction of terraces influences soil carbon dynamics by land-use change and the alteration of local topography and hydrological conditions (Shi et al., 2019; Stavi et al., 2019). Although the impact of terracing on soil organic carbon (SOC) stocks has been studied in diverse regions in Europe (Curtaz et al., 2015; Dunjó et al., 2003; Walter et al., 2003), Asia (Chen et al., 2020; Shi et al., 2019), South America (Antle et al., 2007), and Africa (Kagabo et al., 2013), the mechanisms responsible for the observed $\mathrm{C}$ gain and loss due to terracing are unclear. For example, both positive and negative effects of terracing on SOC stock have been reported (Gao et al., 2020; Chen et al., 2020; Brown et al., 2021). This knowledge gap limits our ability to evaluate how SOC stocks in terraced systems will respond to present and future environmental change such as terrace degradation or land-use change.

Terraces are developed through active cut or fill processes conducted along hillslopes or as a consequence of erosion, deposition, and cultivation (Mesfin, 2016). Soil redistribution during terrace development results in an exposure of the subsurface soil at the cut or eroding section, as well as burial of the original topsoil at the fill or deposition section. Thus, the impacts of terrace construction on SOC dynamics can be compared to the mechanisms proposed for erosional impacts given the similar soil redistribution patterns, that is, topsoil removal at erosional position (same as cut section) and soil burial at depositional position (fill section) (De Blécourt et al., 2014; Van Oost et al., 2007). Based on the knowledge from erosional studies, three possible mechanisms that link terracing with SOC stabilization, acting together or separately, should be considered: (i) the removal of topsoil and physical breakdown of soil aggregates during terrace construction enhance the decomposition of SOC (Bailey et al., 2019; Doetterl et al., 2016; Gao et al., 2020); (ii) SOC removal at the cut or eroding section is gradually replaced through continued SOC inputs from new photosynthate and plant litter decomposition (Berhe et al., 2007; Harden et al., 1999); and (iii) burial of the original topsoil at the fill or depositional section results in reduced SOC decomposition rates by changing the environmental context for SOC decomposition, e.g., providing a low-mineralization context by reducing oxygen availability in soil pore space and increasing soil water content (Berhe et al., 2007; Vandenbygaart et al., 2012; Wang et al., 2014; Wiaux et al., 2015). The status of SOC stocks of terraces but also to what extent terraced soil systems will represent a net SOC loss or sink largely depend on the magnitude by which the three mechanisms identified above interact and govern SOC dynamics over time.

Predicting the sensitivity of SOC decomposition to temperature change is vital to evaluate the warming-induced changes in soil SOC stock and its feedbacks to climate change (Kirschbaum, 1995; Knorr et al., 2005). However, the fundamental drivers and basic patterns of the temperature sensitivity of SOC decomposition in agricultural terraces have been poorly described so far. In a recent study the effect of terrace construction on soil $\mathrm{CO}_{2}$ emission and temperature sensitivity on the Chinese Loess Plateau was reported. However, the simulation of topsoil removal during terrace construction only reflected the short-term $(<2$ years) response and mechanisms (Gao et al., 2020). On the basis of the fundamental principles of enzyme kinetics, temperature sensitivity of SOC decomposition $\left(Q_{10}\right)$ should be determined by the chemical complexity of SOC molecules and by the availability of the SOC substrate to decomposers (Davidson and Janssens, 2006). On the one hand, chemically more complex SOC molecules (thus SOC of low quality), that is, those that require a high activation energy to degrade, should have a higher $Q_{10}$ than SOC of higher substrate quality (Bosatta and Ågren, 1999). On the other hand, environmental factors (e.g., SOC protection) as a constraint on substrate availability should have a negative effect on observed $Q_{10}$ values (Gillabel et al., 2010). According to the fundamental principles mentioned above, the buried SOC stock at fill sections of a terrace is likely to be less sensitive to warming given the high quality of this $\mathrm{C}$ stock. However, the labile fraction of this buried SOC stock might be gradually decomposed or transferred into protected SOC fractions as the terrace system ages (Wang et al., 2014). This changes the SOC quality and protection (and hence substrate availability) over time. We hypothesize that the terrace age is a fundamental driver of the evolution of soil geochemical properties, which in turn determines the SOC protection and quality and thus SOC stabilization and temperature sensitivity. These time-dependent mechanisms may have important implications for the future status of terrace SOC and its feedbacks to climate change.

The overall objective of this study is to improve the mechanistic understanding of SOC dynamics in agricultural terraces and its potential feedback to climate change. To achieve this, we combined SOC fractionation experiments and temperature sensitivity incubations with measurements of relative terrace soil burial age on a prehistoric agricultural terrace system in the Ingram Valley of NE England. The detailed objectives of this study are to investigate (i) the factors controlling SOC stabilization in old agricultural terraces and (ii) the associated patterns of SOC temperature sensitivity.

\section{Material and methods}

\subsection{Study sites}

The study area is located in the Ingram Valley (Fig. 1a) in the Cheviot Hills of NE England within the Northumberland National Park $\left(55^{\circ} 26^{\prime} 26.14^{\prime \prime} \mathrm{N}, 1^{\circ} 59^{\prime} 49.52^{\prime \prime} \mathrm{W}\right)$. This region is characterized by maritime temperate climate with an average monthly temperature that ranges between $-1{ }^{\circ} \mathrm{C}$ (in Febru- 


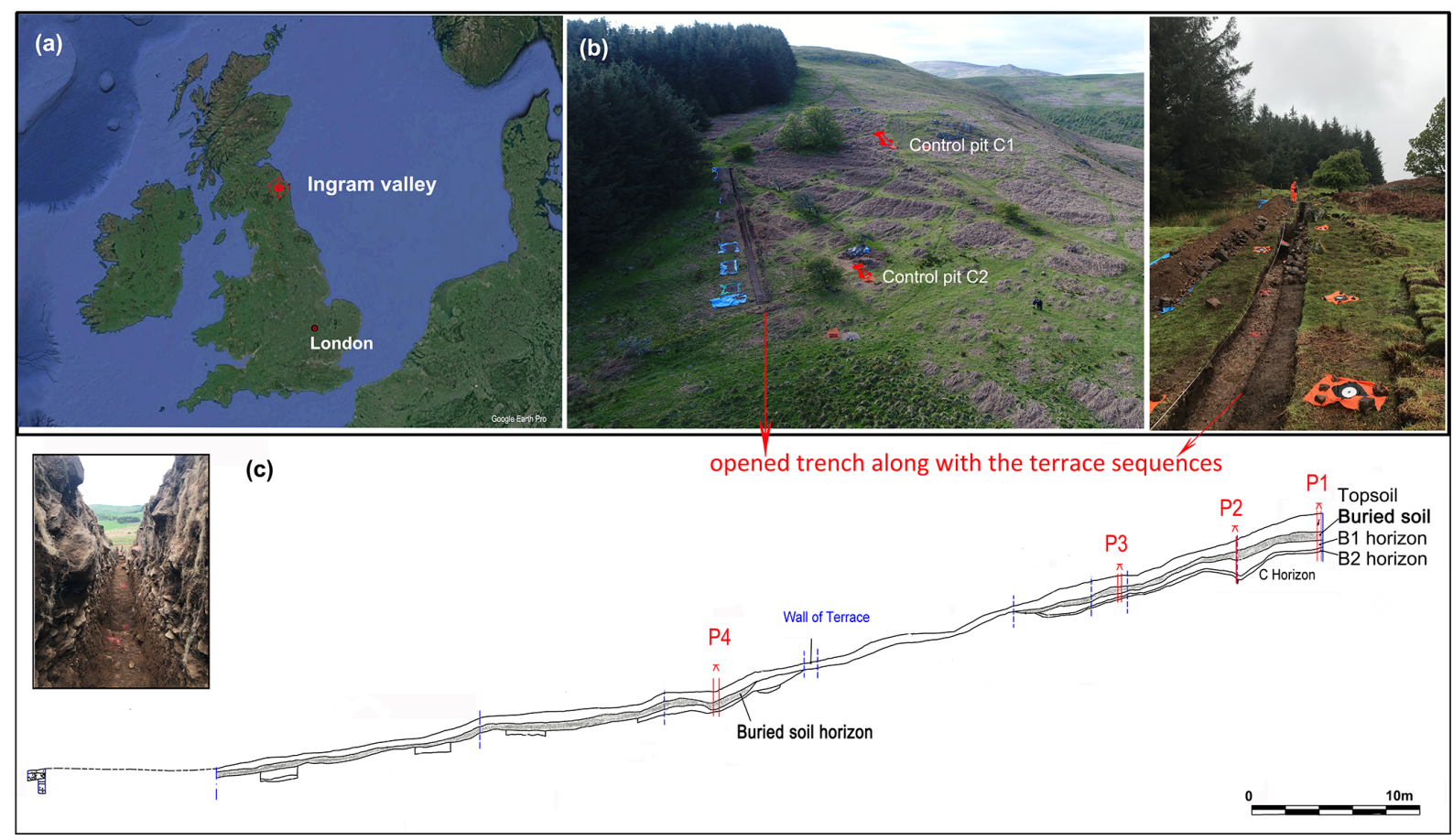

Figure 1. Map of (a) studying area (from (CGoogle Maps), (b) sampling site, and the (c) excavated terrace trench and sampling positions.

ary) and $18{ }^{\circ} \mathrm{C}$ (in July and August) and an average annual rainfall of around $650 \mathrm{~mm}$ (https://www.meteoblue.com, last access: 20 May 2020). Umbrisols have developed from Andesite igneous bedrock of the Cheviot Volcanic Formation which formed approximately 393 to 419 million years ago in the Devonian (British Geological Survey, 2018). The study site complex is one of the largest monuments in England $\left(5.7 \mathrm{~km}^{2}\right)$ and is known as a multi-period archeological landscape, as well as currently also being investigated as part of project TerrACE (https://www.terrace.no/, last access: 3 December 2021). Previous archeological investigations during 1997-1999 (Frodsham and Waddington, 2004) indicate that the cultivation terraces have a prehistoric origin and date back as far as the early Bronze Age, ca. 1800-1500 BC. The landscape at the time the terraces were built was likely dominated by dwarf shrubs (Ericaceae) and grasses, while during the Romano-British period cereals were identified in a pit feature cut into one of the terrace surfaces (Frodsham and Waddington, 2004). The study area is covered by terraces in a small area of ca. $9000 \mathrm{~m}^{2}$ (Fig. 1c).

\subsection{Soil sampling}

Topographic data in the sampling area were collected through structure-from-motion (SfM) photogrammetry technique integrating ground-based and UAV (nadir and oblique) images for a complete and detailed survey of the terrace system (Cucchiaro et al., 2020a). This technique allowed for the generation of high-resolution digital terrain models at 0.25
$0.10 \mathrm{~m}$ resolution that helped identify the extent and shape of seven prehistoric agricultural terraces. Moreover, the output of the SfM workflows as point clouds allowed for the extraction of profiles and sections of the opened trench (Cucchiaro et al., 2020b). A detailed stretch map was created (Fig. 1c; Cockcroft and Waddington, unpublished technical report, 2020) for supporting data interpretation. In order to produce a continuous section through seven cultivation terraces, a trench measuring $63 \mathrm{~m}$ long by $1.5 \mathrm{~m}$ wide was excavated in May 2019 (Fig. 1b). The trench was then carefully cleaned to the depth of the weathered bedrock surface in order to expose the full nature and extent of any archeological features, structures, and deposits where they survive. Four terraces (P1, P2, P3, P4) were sampled in detail along the trench in order to cover the full range of potential burial ages present in the sequence (Fig. 1). Additionally, two control soil pits $(\mathrm{C} 1, \mathrm{C} 2)$ were excavated in proximity to the terraces to provide an undisturbed soil profile, that is, a soil profile that was not subjected to terracing. Soil samples were collected every $5 \mathrm{~cm}$ except for P1 where a different depth interval was used for subsoil layers (Table 1). Thus, whilst our sampling approach only covers one field trench, our approach is a suitable compromise between the need for spatial representativeness of soil data and the logistical criteria for detailed geo-archeological excavations at selected sites. The number of highly depth-resolved samples collected this way does allow for the analysis of continuous trends of specific soil parameters within terraced and non-terraced profiles along a sequence of spatially and temporally clearly distinct 
Table 1. Depth layers selected for soil analysis from sampled terraces.

\begin{tabular}{|c|c|c|c|c|c|}
\hline $\begin{array}{l}\text { Sampling } \\
\text { positions }\end{array}$ & $\begin{array}{l}\text { Sampling } \\
\text { depth }(\mathrm{cm})\end{array}$ & $\begin{array}{l}\text { Bulk density } \\
(\mathrm{cm})\end{array}$ & $\begin{array}{l}\text { SOC fractionation } \\
\text { soil incubation }(\mathrm{cm})\end{array}$ & $\begin{array}{c}\text { Total SOC } \\
\text { (depth interval, } \mathrm{cm})\end{array}$ & $\begin{array}{c}\mathrm{pXRF} / \mathrm{pOSL} \\
\text { (depth interval, } \mathrm{cm} \text { ) }\end{array}$ \\
\hline Control C1 & 70 & $\begin{array}{r}0-10 ; 30-40 ; \\
50-60\end{array}$ & $\begin{array}{r}0-10 ; 30-45 \\
60-70\end{array}$ & 5 & 5 \\
\hline Control C2 & 45 & $0-10 ; 30-40$ & $0-10 ; 30-45$ & 5 & 5 \\
\hline Terrace P1 & 195 & $0-10$ & $\begin{array}{r}0-10 ; 50-70 ; \\
90-100 ; 140-150\end{array}$ & $\begin{array}{r}0-30: \\
5 ; \\
30-50: \\
15 ; \\
>50: \\
10\end{array}$ & 5 \\
\hline Terrace P2 & 150 & $\begin{array}{r}0-10 ; 30-40 ; \\
60-70\end{array}$ & $\begin{array}{r}0-10 ; 30-45 ; 60-70 \\
80-90\end{array}$ & 5 & 10 \\
\hline Terrace P3 & 80 & $0-10 ; 30-40$ & $0-10 ; 30-45 ; 60-70$ & 5 & 5 \\
\hline Terrace P4 & 105 & $\begin{array}{r}0-10 ; 30-40 \\
60-70\end{array}$ & $0-10 ; 30-45 ; 60-70$ & 5 & 5 \\
\hline
\end{tabular}

agricultural terraces. A total of 91 depth-explicit soil samples have been collected this way along the terrace sequence and an additional 23 depth-explicit samples collected from the control pits for further analysis.

\subsection{SOC fractionation}

A total of $40 \mathrm{~g}$ of $5 \mathrm{~mm}$ sieved air-dried soils was fractionated in duplicate to obtain SOC fractions for selected soil layers, representing different layers within each undisturbed and terraced soil (topsoil $0-10 \mathrm{~cm}$, shallow subsoil $30-45 \mathrm{~cm}$, deeper subsoil $\geq 60-70 \mathrm{~cm}$ ). These depth intervals were chosen to maximize the variation in terrace burial age, which we will use to investigate its effect on $\mathrm{C}$ dynamics. We used a fractionation scheme based on the conceptual SOC model proposed by Six et al. $(2002,1998)$ applying a simplified version of its fractionation protocol (Doetterl et al., 2015). Total SOC was fractionated into coarse particulate organic carbon $(\mathrm{cPOM},>250 \mu \mathrm{m})$, microaggregateassociated SOC $(M, 250-53 \mu \mathrm{m})$, and non-aggregated silt and clay $\mathrm{SOC}(\mathrm{S}+\mathrm{C},<53 \mu \mathrm{m})$. In brief, the microaggregate isolator was placed on a reciprocal shaker, and $20 \mathrm{~g}$ of airdried soils, together with 50 glass beads, was added on top of a sieve with a $250 \mu \mathrm{m}$ mesh size. Then, the isolator and sieve were flushed continuously with deionized water while shaking at low (=150 rpm) speed for up to 5 min until water flowing out of the device onto a $53 \mu \mathrm{m}$ mesh size sieve was clear and all aggregates on top of the $250 \mu \mathrm{m}$ mesh size sieve were broken up. Materials left on the $250 \mu \mathrm{m}$ mesh size sieve were interpreted as cPOM plus sand. Materials left on the $53 \mu \mathrm{m}$ mesh size sieve were interpreted as microaggregates, and all $<53 \mu \mathrm{m}$ particles were interpreted as non-aggregated silt and clay. All fractions were analyzed for total $\mathrm{C}$ and $\mathrm{N}$ using a vario Max CN Analyzer (Elementar GmbH, Germany). Samples showed no reaction when treated with $10 \% \mathrm{HCl}$ and were considered free of carbonates. cPOM was interpreted as unprotected SOC, while $M$ and $\mathrm{S}+\mathrm{C}$ were interpreted as mineral-protected SOC in our analysis (Gillabel et al., 2010; Six et al., 2002).

\subsection{Temperature-sensitivity based on soil incubations}

Three replicate samples of $30 \mathrm{~g}$ of $2 \mathrm{~mm}$ sieved bulk soils from the selected soil layers were chosen for the fractionation (see Table 1) of each soil profile and were incubated at two different temperature levels $\left(20\right.$ and $30^{\circ} \mathrm{C}$ ) using $380 \mathrm{~mL}$ sealed jars. A $10 \mathrm{~d}$ pre-incubation was carried out in order to avoid $\mathrm{CO}_{2}$ pulses caused by soil sample preparation (i.e., sieving, drying, and rewetting), then respiration was monitored during 8 weeks while keeping moisture $(60 \%$ of soil water holding capacity) constant during the whole experiment by periodically adding demineralized water to the samples. The temperature and moisture level used in the incubation were chosen to provide optimal conditions for microbe activity, thus inducing the specific potential maximum heterotrophic respiration (SPR) (Paul et al., 2001). Then, respiration data were collected to calculate heterotrophic potential specific soil respiration, expressed as $\mathrm{CO}_{2}-\mathrm{C}$ per unit mass of soil C. For this, every $7 \mathrm{~d}$ throughout the experiment gas samples within the incubation jars were circulated through a LI-830 $\mathrm{CO}_{2}$ gas analyzer (LI-COR, Inc., the Netherlands) for determining $\mathrm{CO}_{2}$ concentration. $\mathrm{CO}_{2}$ production was analyzed as the average SPR over the whole incubation period (pre-incubation excluded). To avoid $\mathrm{CO}_{2}$ saturation effects influencing microbial decomposition processes, the incubation jars were flushed with fresh air after each measurement and left open between measurement cycles with jars covered by parafilm to allow for gas exchange while limiting water loss through evaporation. Temperature sensitivity of SPR $\left(Q_{10}\right)$ was calculated as the difference in SPR of the same 


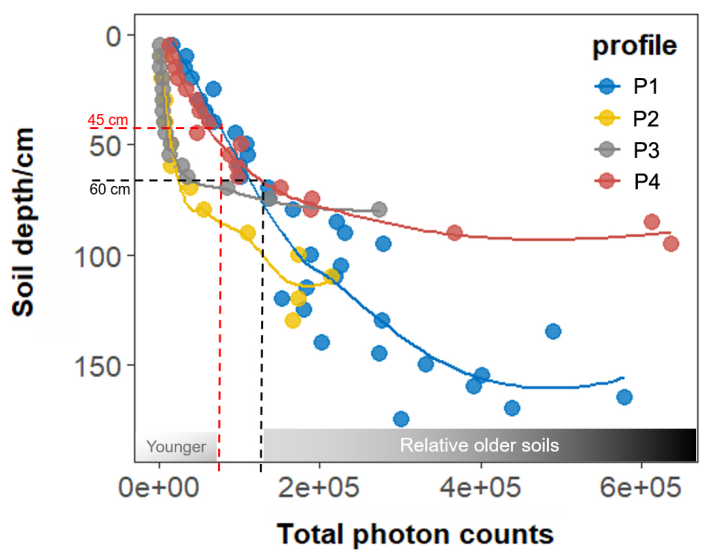

Figure 2. The total photon counts versus soil depth in terrace soils. The two soil burial-age categories are shown with dashed lines (i.e., above $45 \mathrm{~cm}=$ young, below $60 \mathrm{~cm}=$ old).

aliquot samples at 20 to $30^{\circ} \mathrm{C}$ incubation temperature (Doetterl et al., 2018; Paul et al., 2001). The average uncertainty for SPR measurement was $0.5 \mu \mathrm{g} \mathrm{h}^{-1} \mathrm{~g} \mathrm{SOC}^{-1}$.

\subsection{Soil burial age and soil geochemical properties along the agricultural terraces}

The main total elemental contents ( $\mathrm{Fe}, \mathrm{Al}, \mathrm{Mn}, \mathrm{Sr}, \mathrm{Rb})$ of the bulk soil were measured using an Olympus Vanta M series portable energy dispersive X-ray fluorescence spectrometer (pXRF) at each $5 \mathrm{~cm}$ depth for all terrace profiles (Table 1). The $\mathrm{Rb}: \mathrm{Sr}$ ratio was applied as a proxy for weathering intensity since both elements fractionate during the weathering processes due to their different chemical behavior. Because of the relative inertness of $\mathrm{Rb}$ compared to $\mathrm{Sr}$, a higher ratio of $\mathrm{Rb}: \mathrm{Sr}$ indicates a higher degree of soil weathering and higher age (An et al., 2018). Soil $\mathrm{pH}$ was determined with a soil : solution ratio of $1: 2.5(\mathrm{w} / \mathrm{v})$ with $0.01 \mathrm{M} \mathrm{CaCl}_{2}$ solution using a pH meter (Mettler Toledo MP220, Mettler Toledo, Switzerland). Soil texture was analyzed using a laser diffraction particle size analyzer (model LS 13 320; Beckman Coulter Inc., Fullerton, USA) after ultrasonic dispersion and removal of organic matter using $\mathrm{H}_{2} \mathrm{O}_{2}(35 \%)$ (Beuselinck et al., 1998).

Optically stimulated luminescence (OSL) has been widely applied for sediment dating (Brown, et al., 2021). To establish a chronology of soil burial along the terrace sequence, OSL data were obtained using a portable OSL (pOSL) reader. A pOSL reader was used since it has successfully and frequently been applied in similar settings (e.g., Muñoz-Salinas et al., 2011; Portenga et al., 2016; Porat et al., 2019). When compared to conventional OSL dating, pOSL is more efficient in terms of time, cost, and labor and can therefore be used for large, untreated samples, especially to clarify deposition processes (Muñoz-Salinas et al., 2011; Porat et al., 2019). The pOSL was recorded at $5 \mathrm{~cm}$ intervals through- out all terrace profiles (P1-P4). Luminescence samples were collected in bulk using blackout bags to block out the light. The bags were held against the cleaned section at the sampling location, and soil was scooped into them, avoiding exposure to the light. Counts were based on $60 \mathrm{~s}$ of exposure to blue light using the SUERC (Scottish Universities Environmental Research Centre) meter. Here, besides others, the signal intensity is a function of mineral composition, content of moisture, age, etc. As mineral composition, as well as moisture content, was relatively homogenous throughout individual profiles, age is the main discriminant for pOSL activity. The consistently low photon counts at the top of the soil profiles were therefore taken as an indicator of very young ages. Thus, pOSL activity was taken as a proxy for the relative terrace soil burial age (following Muñoz-Salinas et al., 2011) in which it increased monotonically with soil depth. Note that the interpretation of relative terrace soil burial age based on pOSL was only applied with depth within individual soil profiles rather than between profiles to rule out batch effects caused by the drying out of the samples which could not be processed in the field. Where pOSL did not increase consistently with depth, it was considered to indicate soil heterogeneity and mixing. Lastly, soil samples were classified into relatively younger and older soils based on a (visual) change in the soil depth-age relation (see Fig. 2). Then, the relationship of SOC fraction abundance and $Q_{10}$ to soil burial age was analyzed by comparing sample groups along the four investigated terraces. The pOSL signal showed that the terrace soil profiles gradually become older towards the bottom (Fig. 2), suggesting that the terraces are most likely developed by stone lines which gradually catch soil material moving downslope, resulting in the former "topsoil" layers being buried in deep soil layers. Therefore, the soil burial age was supposed to play a dominant role in terracing SOC dynamics.

\subsection{Statistical analysis}

All statistical analyses were performed by R 3.6.3 (R Development Core Team, https://www.r-project.org/, last access: 6 December 2021). The differences of SOC concentration between control and terraced soil layers were analyzed with unpaired $t$ tests. The model fitting function of "stat_fit_glance" from the "ggpmisc" R package was used to derive the non-linear regression model between terrace soil burial age and SOC variables $\left(Q_{10}\right.$, SPR, SOC fractions). Linear regression and simple correlation were used to examine the relationship between SOC fractions, $Q_{10}, \mathrm{pH}$, and soil texture. Differences in means of SPR and $Q_{10}$ between the buried and non-buried soil layers were tested by unpaired $t$ tests. The "outlierTest" function from the "car" package was used to identify outliers $(P<0.05)$ based on a given model (i.e., cPOM $\% \sim Q_{10} ; \mathrm{S}+\mathrm{C} \% \sim \mathrm{SPR}$; total photon counts $\sim \log \left(Q_{10}\right)$; total photon counts $\sim \log (\mathrm{SPR})$ ). The observation for the $Q_{10}$ from P1 topsoil (see gray point in Fig. 5a) was identified as an outlier and was therefore not 
included in the correlation and regression analysis. Significance in all cases was assessed at $P<0.05$. All figures were produced by R package "ggplot2".

\section{Results}

\subsection{SOC fractions composition, temperature sensitivity, and soil respiration}

For the $0-50 \mathrm{~cm}$ soil layers, no significant difference in SOC concentrations could be observed between the terrace and control soil layers (Fig. 3a). Below $50 \mathrm{~cm}$, soil layers in control profiles showed significant lower SOC contents relative to the terrace soil layers $(P<0.05)$. The SOC contents (Fig. S1 in the Supplement) of P1 for $95-125 \mathrm{~cm}, \mathrm{P} 2$ for $65-$ $85 \mathrm{~cm}, \mathrm{P} 3$ for $50-65 \mathrm{~cm}$, and P4 for $55-70 \mathrm{~cm}$ depth layers were higher than at the control profiles (C). In combination with the high degree of chemical weathering, we interpreted these layers as buried A horizons (detailed in S1 in the Supplement).

Considering all profiles, topsoil SOC was mainly composed of SOC associated with the $M$ fraction, followed by cPOM and $\mathrm{S}+\mathrm{C}$ (Fig. $3 \mathrm{~b}$ ). For the $30-45 \mathrm{~cm}$ depth layer, terrace soil layers contained twice as much $\mathrm{cPOM}$-associated $\mathrm{C}$ than the corresponding soil layer in the control profiles. Below $60 \mathrm{~cm}$ (i.e., the buried horizons), the contribution of cPOM to total SOC in terrace soil layers was 1.7 times higher than in soil layers of the control, while a comparable proportion of physical-protected SOC $(M \%)$ was found in terrace and control soil layers. SPR and SOC temperature sensitivity $\left(Q_{10}\right)$ varied significantly across soil layers. On average, buried soil layers showed a significantly lower SPR than the non-buried layers ( $P<0.05$, Fig. 4$)$, while for $Q_{10}$ no significant difference between buried and non-buried soil layers could be found.

\subsection{Controls on terrace SOC stability}

A non-linear regression analysis was used to identify the effect of total photon counts, which was treated as a proxy for soil burial age, on SOC fraction distributions and on SPR. We found that SPR was negatively related to total photon counts (Fig. 5a), indicating that the terrace soil burial age was an important control on SPR. Furthermore, cPOM and $\mathrm{S}+\mathrm{C}$ fractions were significantly correlated with burial age (Fig. 5b), in which a shift from cPOM to $\mathrm{S}+\mathrm{C}$-associated SOC fractions was observed with increasing age. No significant relationship between SPR and measured soil geochemical properties (e.g., $\mathrm{pH}$, soil texture, and soil elements) was found (Table $2, P<0.05$ ).

\subsection{Terrace soil burial age and SOC temperature sensitivity $\left(Q_{10}\right)$}

A significant relationship between $Q_{10}$ and total photon counts was observed (Fig. 5a). This relationship suggests that $Q_{10}$ values decline rapidly with the increasing age for young soil horizons, while for older soil horizons $Q_{10}$ remained relatively constant or increased in the oldest soil horizons. Linear regression further showed that for relatively younger soil horizons (Fig. 2), $Q_{10}$ values were significantly related to the proportion of $\mathrm{S}+\mathrm{C}$-associated $\mathrm{C}$ and $\mathrm{cPOM}$-associated $\mathrm{C}$, while for old soil horizons no such strong relation was found (Fig. 6).

To further identify the underlying controls, we linked the patterns of $Q_{10}$ to soil C: N ratio and measured soil geochemical properties (e.g., pH, soil texture). We found that $Q_{10}$ was significantly correlated to the C: N ratio of bulk soil, $M$, and $\mathrm{S}+\mathrm{C}$ fractions (Table 3). In addition, Fig. 7 shows that the $\mathrm{C}: \mathrm{N}$ ratio of bulk soil and SOC fractions first decreased with burial age then significantly increased $(P<0.05)$ when the terrace soils became very old. Furthermore, the $Q_{10}$ was significantly correlated to clay content at relatively younger burial ages, while silt and sand contents were significantly correlated to $Q_{10}$ at relatively older burial ages (Table $2, P<0.05$ ).

\section{Discussion}

\subsection{Terrace SOC stabilization: importance of carbon burial and terrace age}

Previous work has highlighted that carbon burial due to soil redistribution has important implications for SOC stabilization in eroding landscapes (e.g., VandenBygaart et al., 2012; Van Oost et al., 2012; Wang et al., 2014, 2015). Our results show that the buried soil layers have a significantly lower SPR than the non-buried layers (Fig. 4), indicating that carbon burial by terracing reduces soil potential respiration and is therefore a mechanism that contributes to SOC stabilization in agricultural terraces. Although buried A horizons in terrace profiles contain 1.7 times more unprotected SOC (cPOM, Fig. 4) than non-terraced profiles, the less favorable environmental conditions for microbial decomposers (e.g., mostly lack of oxygen and water saturation) are likely to constrain in situ mineralization rates of SOC (De Blécourt et al., 2014; Wang et al., 2014; VandenBygaart et al., 2015). This resulted in a partially preserved but highly biologically processed SOC stock in terraced soils with a lower SPR relative to non-terraced soils. Soil redistribution during terrace development results in an exposure of the subsurface soil at the cut or eroding section, as well as burial of the original topsoil at the fill or depositional section. The terraced area of the study site is located in the middle and upper part of the hill. The pOSL signal showed that the terrace soil profiles 

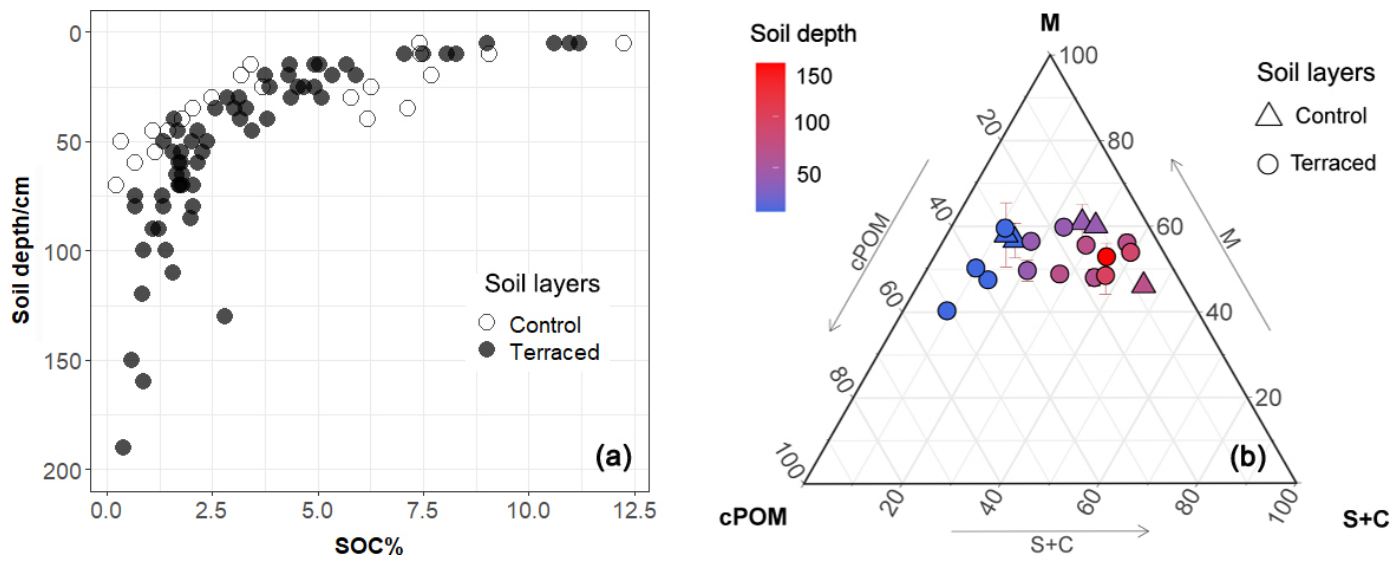

Figure 3. (a) Depth profile of SOC concentration. The significant difference $(P<0.05)$ in SOC concentration between the terraced and control soil layers can be found below $50 \mathrm{~cm}$ layers. There is no such significant difference at $0-50 \mathrm{~cm}$ layers. (b) Ternary plot of SOC fractions in percentage of total SOC. $M=$ microaggregate-associated SOC; $\mathrm{CPOM}=$ coarse particulate SOC; $\mathrm{S}+\mathrm{C}=$ silt- and clay-associated SOC Color bar represents the soil depth $(\mathrm{cm})$. Error bars denote 1 standard deviations of the $M$ fraction measurements $(N=2)$.

Table 2. Relationships between SPR, SOC temperature sensitivity $\left(Q_{10}\right)$, and measured soil geochemical properties.

\begin{tabular}{|c|c|c|c|c|c|c|c|c|}
\hline & $\mathrm{pH}$ & Clay & Silt & Sand & $\mathrm{Fe}$ & $\mathrm{Mn}$ & $\mathrm{Al}$ & $\mathrm{Rb} / \mathrm{Sr}$ \\
\hline \multicolumn{9}{|c|}{ Relatively younger layers } \\
\hline$Q_{10}$ & -0.68 & $-0.90^{*}$ & 0.35 & 0.31 & -0.75 & -0.55 & -0.56 & -0.14 \\
\hline SPR & -0.17 & -0.40 & -0.15 & 0.43 & -0.09 & -0.45 & -0.38 & 0.72 \\
\hline \multicolumn{9}{|c|}{ Relatively older layers } \\
\hline$Q_{10}$ & -0.44 & -0.69 & $-0.79^{*}$ & $0.80^{*}$ & 0.66 & -0.29 & 0.49 & 0.20 \\
\hline SPR & 0.05 & 0.17 & -0.28 & 0.17 & -0.10 & 0.18 & -0.32 & 0.66 \\
\hline
\end{tabular}

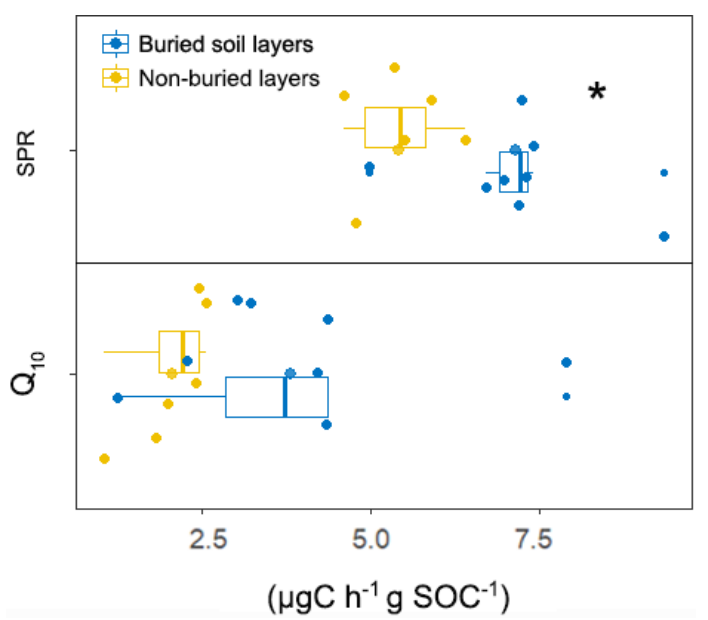

Figure 4. Boxplot of soil potential respiration (SPR) rates and SOC temperature sensitivity $\left(Q_{10}\right)$. The ${ }^{*}$ signifies differences in SPR or $Q_{10}$ between buried and non-buried soil layers $(P<0.05)$. Identification of buried soil layers is based on the depth profile of SOC concentration and soil chemical weathering degree with support from the stretch map in Fig. 1 (see details in S1 in the Supplement).
Table 3. Relationship between SOC temperature sensitivity $\left(Q_{10}\right)$ and $\mathrm{C}: \mathrm{N}$ ratios of bulk soil and SOC fractions.

\begin{tabular}{lcccc}
\hline & Bulk soil & cPOM & $\mathrm{M}$ & $\mathrm{S}+\mathrm{C}$ \\
\hline$Q_{10}$ & $0.60^{*}$ & 0.03 & $0.61^{*}$ & $0.62^{*}$ \\
\hline$* P<0.05 . N=13$. cPOM $=$ coarse particulate $\mathrm{C} ;$ \\
$\begin{array}{l}M=\text { microaggregate-associated } \mathrm{C} \text { and } \mathrm{S}+\mathrm{C}=\text { silt- and } \\
\text { clay-associated C. }\end{array}$
\end{tabular}

gradually become older towards the bottom (Fig. 2), suggesting that the current terraces are most likely developed by stone lines which gradually catch soil material eroded from the summit. Our sampling strategy therefore mainly reflects the $\mathrm{C}$ stabilization mechanism of the depositional rather than the eroding part of the hill.

The significant relationship between SPR and total photon counts (Fig. 5a) indicates that the time since terracing is a key factor controlling the stability of SOC in terrace soils. More specifically, SPR declines rapidly with increasing terrace soil burial age until soils become relatively older, leading to an increase in SOC stock in the old terraces compared 

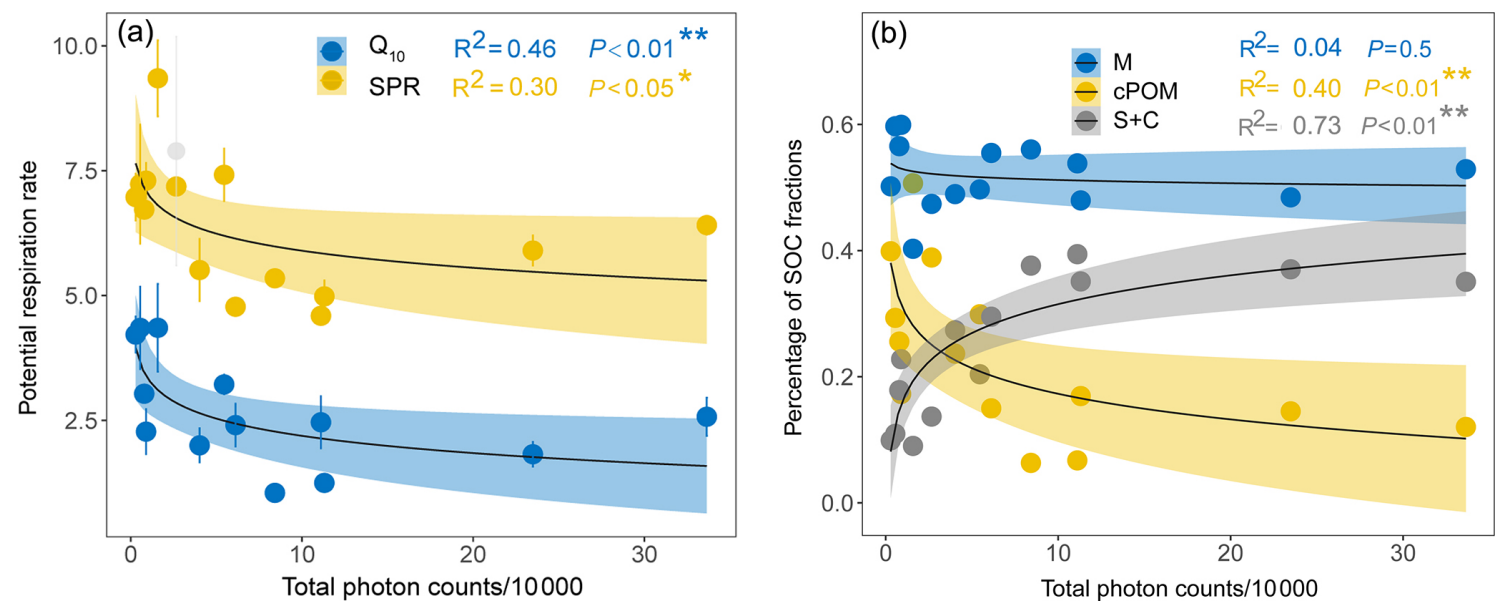

Figure 5. Relation between relative terrace soil burial age (total photon counts) and (a) SPR rates and SOC temperature sensitivity to decomposition $\left(Q_{10}\right)$, and (b) contribution of SOC fraction to total SOC. Error bars denote 1 standard deviation of SPR measurements $(N=3)$. Formula: $y=\log (x)$. cPOM = coarse particulate SOC; $M=$ microaggregate-associated SOC; $\mathrm{S}+\mathrm{C}=$ silt- and clay-associated SOC. Data points are from all terrace profiles. ${ }^{*}=P<0.05$; $^{* *} P<0.01$.
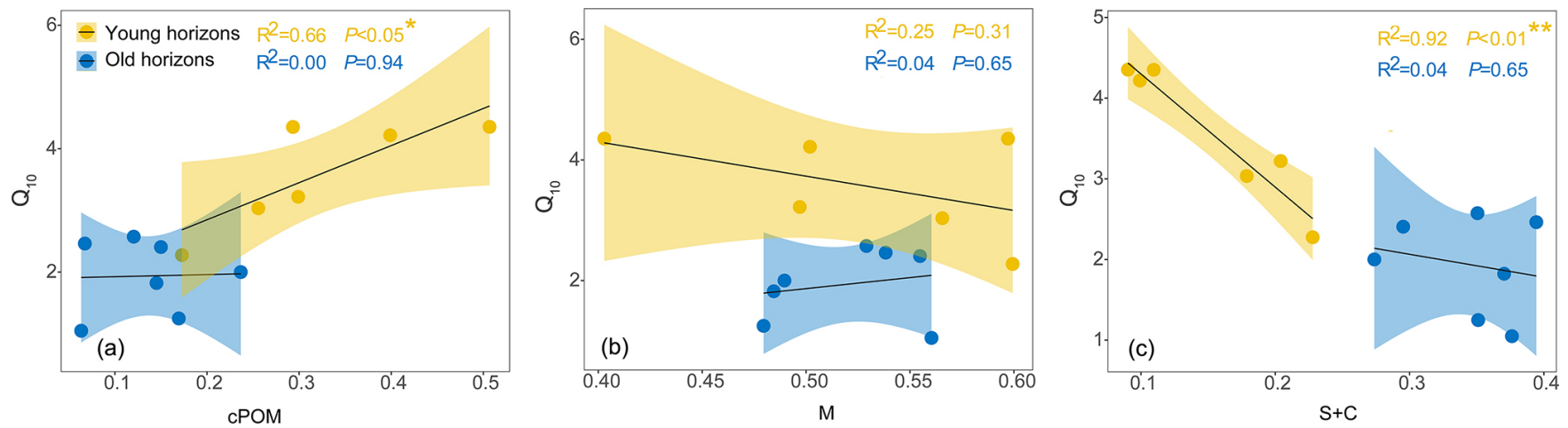

Figure 6. Relationship between SOC temperature sensitivity $\left(Q_{10}\right)$ and (a) coarse particulate SOC (cPOM), (b) microaggregate-associated SOC $(M)$, and (c) silt- and clay-associated SOC $(\mathrm{S}+\mathrm{C})$ for relatively younger and older terrace soil horizons $($ Fig. 2$) .{ }^{*}=P<0.05$; ** $P<0.01$.

to the non-terraced landscape (Chen et al., 2020). In addition, we found that the percentage of unprotected (cPOM) and mineral-protected $(\mathrm{S}+\mathrm{C}) \mathrm{SOC}$ fraction is significantly related to the terrace soil burial age (Fig. 5b), indicating a shift from active SOC fractions with short residence times (higher SPR) at relatively younger burial ages to mineralprotected SOC fractions with long residence times (lower SPR) at relatively older burial ages. This clear shift to more processed recalcitrant SOC with age is the underlying process leading to SOC stabilization in terrace soils. By comparing the cPOM fraction of the topsoil layer $(0-10 \mathrm{~cm})$ with previous topsoil (burial horizon, $>60 \mathrm{~cm}$ ), we estimated that about $23-27 \%$ of the cPOM fraction in buried horizons has been decomposed or transferred into physical-protected or mineral-protected SOC since the terrace were built (Fig. 3b). Given that the buried soil horizons of terrace profiles still contain 1.7 times more unprotected SOC (cPOM) than SOC at similar soil depths in control profiles, we suggest that SOC cycling in the current terrace has not yet reached a steady state and that the SOC stock is most likely to slowly decrease due to cPOM decomposition in the future.

\subsection{Main controls on temperature sensitivity}

According to the Arrhenius equation, $Q_{10}$ of SOC decomposition is theoretically jointly determined by the molecular complexity (SOC quality) and availability of the substrates (referred to here as SOC protection) (Davidson and Janssens, 2006). In general, enzymatic decomposition of biochemically recalcitrant substrates (lower SOC quality) requires more activation energy to degrade and should have a higher temperature sensitivity than the decomposition of more labile substrates (Bosatta and Ågren, 1999; Craine et al., 2010a). However, environmental constraints (SOC physical or chemical protection, soil acidity, etc.) can reduce substrate availability, dampening the intrinsic temperature sensitivity (Gill- 

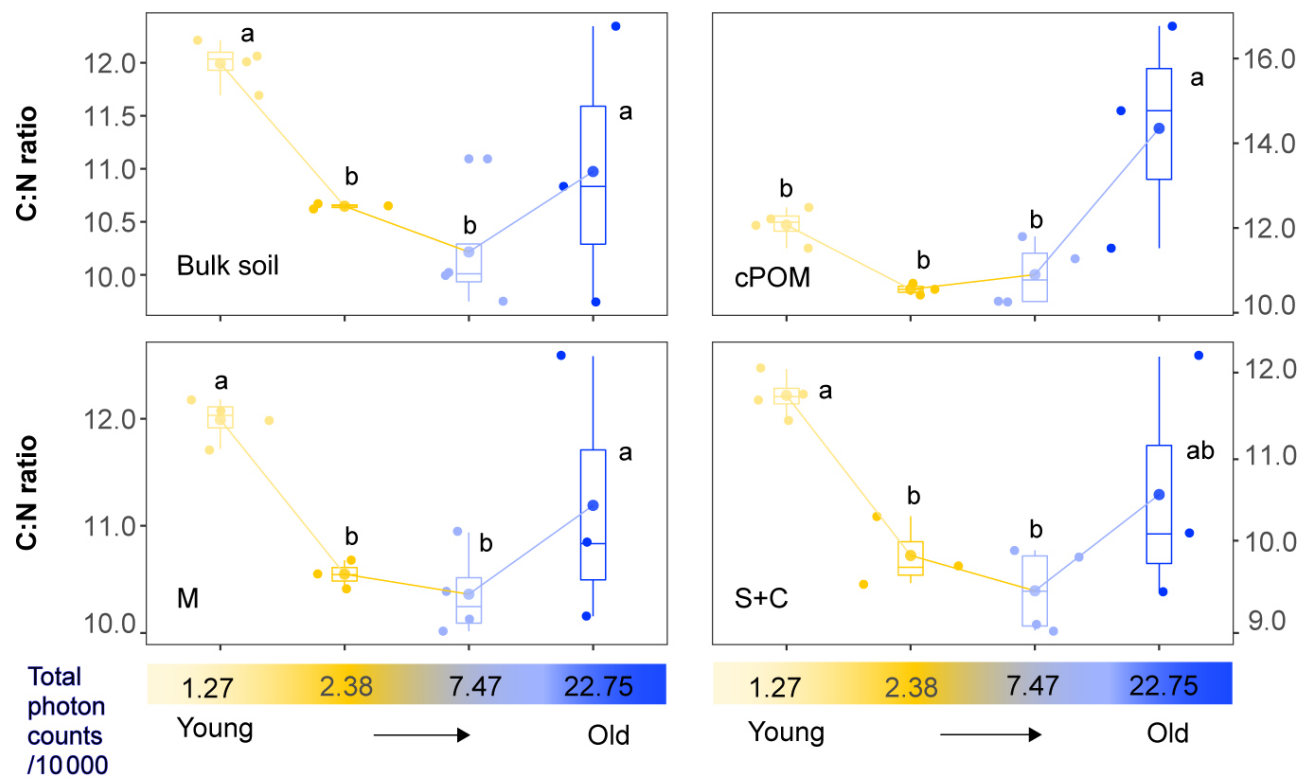

Relative age of soil horizons

Figure 7. Boxplots of $\mathrm{C}: \mathrm{N}$ ratios for bulk soil and SOC fractions along the gradient of terrace soil burial age (total photon counts). $\mathrm{cPOM}=$ coarse particulate SOC; $M=$ microaggregate-associated SOC and S $+\mathrm{C}=$ silt- and clay-associated SOC. Significant differences in $\mathrm{C}: \mathrm{N}$ ratios between soil age gradients were indicated by different lowercase letters $(P<0.05)$.

abel et al., 2010). It has been reported that soil $\mathrm{pH}$ is an important control on $Q_{10}$ at the landscape scale by directly affecting microbial biomass, diversity, and therefore the enzyme activities or indirectly through altering nutrient solubility, mineral matrix, and therefore the substrate availability (e.g., Craine et al., 2010b; Ali et al., 2018). However, in our study soil $\mathrm{pH}$ was not strongly related to SPR or $Q_{10}$ (Table 2) possibly due to the small variation in soil $\mathrm{pH}$ $(\mathrm{pH}=3.71 \pm 0.34)$. Instead, our results showed that at relatively younger burial ages, $Q_{10}$ is negatively related to $\mathrm{S}+\mathrm{C}$ associated SOC fractions (Fig. 6) and clay content (Table 2). This indicates that the adsorption of labile SOC (e.g., dissolved OC) by soil-reactive clay minerals forms organomineral associations (SOC mineral protection) which reduce the substrate availability to decomposers (Kögel-Knabner et al., 2008). As a result, SOC mineral protection attenuates the intrinsic $Q_{10}$, resulting in the rapid decrease in $Q_{10}$ with total photo counts at the relatively young age stage. However, at relatively older soil burial stages, we could not detect any significant correlation between $Q_{10}$ and SOC fractions (Fig. 5a), while $\mathrm{C}: \mathrm{N}$ ratio of bulk soil, $M$, and $\mathrm{S}+\mathrm{C}$ soil fractions were significantly related to $Q_{10}$ (Table 2). More importantly, we observed a significant increase in $\mathrm{C}: \mathrm{N}$ ratio for bulk soil and all SOC fractions at the oldest buried soil layers (Fig. 7). We proposed two possible reasons as to why $\mathrm{C}: \mathrm{N}$ ratios were closely linked to $Q_{10}$, especially in the oldest buried soil layers. Both the depth profile of soil chemical weathering, SOC concentration, and field investigation indicate that these oldest soil horizons (Fig. 7; total photon counts $/ 1000=22.5$ ) are likely to originate from the former buried topsoil (detailed in S1 in the Supplement). The former topsoil may still contain less decomposed organic litter, which is commonly reflected in a higher soil $\mathrm{C}: \mathrm{N}$ ratio (Xia et al., 2021). Alternatively, unlike for fresh litter, SOC with a higher $\mathrm{C}: \mathrm{N}$ ratio is usually considered as lower-quality or recalcitrant substrates which are less bioavailable for soil microorganisms (e.g., Sollins et al., 1996; Liu et al., 2017; Wang et al., 2018). The observed increase in soil $\mathrm{C}: \mathrm{N}$ ratios at greater depths in older terraces might therefore reflect a shift towards poor-quality SOC substrates (Ali et al., 2018), which explains the observed increase in $Q_{10}$ in the oldest soil horizons (i.e., Fig. 5a, Result 3.3). We propose that the latter is more likely in our experiments. Together, our results suggest that the factors controlling SOC temperature sensitivity of terrace soils (SOC mineral protection or $\mathrm{C}: \mathrm{N}$ ratio) change over time. At relatively younger stages of soil burial, the reduction in substrate availability due to the increased SOC mineral protection with aging attenuates the intrinsic $Q_{10}$ of SOC decomposition (Figs. 5a and 6), whereas at the oldest terrace soil burial age, SOC in buried layers reflects an increased $Q_{10}$ probably due to (1) lower C quality (higher $\mathrm{C}: \mathrm{N}$ ratio; Fig. 7) and (2) weaker SOC mineral protection (Fig. 5b; Table 2).

\section{Conclusions}

Terracing currently has buried a substantial amount of former topsoil SOC (De Blécourt et al., 2014). Our results show that although buried terrace soils contained 1.7 times more unpro- 
tected SOC (i.e., coarse particulate organic carbon) than nonterraced soils at comparable soil depths, a significantly lower potential soil respiration was observed relative to a control (non-terraced) profile. This suggests that the burial of former topsoil due to terracing provided a mechanism for enhanced $\mathrm{C}$ stabilization. Furthermore, we found that the evolution of SOC fractions along with terrace soil burial age is related to the depth patterns of specific soil respiration; i.e., there is a shift from active SOC fractions at relatively younger soil burial ages towards more processed recalcitrant SOC fractions at older soil burial ages.

Furthermore, our study provides empirical evidence for the drivers and basic patterns of the temperature sensitivity of SOC decomposition in agricultural terraces. We found that both the $\mathrm{C}: \mathrm{N}$ ratio and SOC mineral protection regulate soil $Q_{10}$. However, which mechanism predominantly controls soil $Q_{10}$ depends on the age of the buried terrace soils. At relatively younger ages of soil burial, the reduction in substrate availability due to the increased SOC mineral protection with aging attenuates the intrinsic $Q_{10}$ of SOC decomposition, whereas at older terrace soil burial ages, higher $\mathrm{C}: \mathrm{N}$ ratios (poor C quality) result in an increased $Q_{10}$ in deep horizons. It is expected that the ongoing evolution of SOC fractions and the associated changes in soil $\mathrm{C}: \mathrm{N}$ ratio due to terrace aging will slowly but steadily destabilize buried former topsoil SOC.

Data availability. All data used and produced in this study are available with the Supplement.

Supplement. The supplement related to this article is available online at: https://doi.org/10.5194/bg-18-6301-2021-supplement.

Author contributions. PZ, KVO, SD, and AGB designed the study. CW, DC, DJF, PZ, AGB, LS, and AL excavated the terrace trench and collected soil samples. SC and PT performed the topography survey. AGB and KVO acquired the research funding. PZ wrote the original draft with input from all co-authors.

Competing interests. The contact author has declared that neither they nor their co-authors have any competing interests.

Disclaimer. Publisher's note: Copernicus Publications remains neutral with regard to jurisdictional claims in published maps and institutional affiliations.

Acknowledgements. The authors would like to thank Ben R. Pears, Rosa Maria Albert, Inger Alsos, Kevin Walsh, and the volunteers who helped with the field excavation in Ingram Valley, UK. The authors also thank Marco Bravin for his assistance with the SOC sample analysis.

Financial support. This research has been financially supported by the European Research Council, H2020 (grant no. TerrACE (787790)). Pengzhi Zhao has been supported by the joint grant from the China Scholarship Council and UCLouvain (no. 201706600009). Kristof Van Oost is a research director of the FNRS Belgium.

Review statement. This paper was edited by Jianming $\mathrm{Xu}$ and reviewed by two anonymous referees.

\section{References}

Ali, R. S., Kandeler, E., Marhan, S., Demyan, M. S., Ingwersen, J., Mirzaeitalarposhti, R., and Poll, C.: Controls on microbially regulated soil organic carbon decomposition at the regional scale, Soil Biol. Biochem., 118, 59-68, https://doi.org/10.1016/j.soilbio.2017.12.007, 2018.

An, F. Y., Lai, Z. P., Liu, X. J., Fan, Q. S., and Wei, H. C.: Abnormal $\mathrm{Rb} / \mathrm{Sr}$ ratio in lacustrine sediments of Qaidam Basin, NE Qinghai-Tibetan Plateau: A significant role of aeolian dust input, Quatern. Int., 469, 44-57, https://doi.org/10.1016/j.quaint.2016.12.050, 2018.

Antle, J. M., Stoorvogel, J. J., and Valdivia, R. O.: Assessing the economic impacts of agricultural carbon sequestration: Terraces and agroforestry in the Peruvian Andes, Agr. Ecosyst. Environ., 122, 435-445, https://doi.org/10.1016/j.agee.2007.02.003, 2007.

Bailey, V. L., Pries, C. H., and Lajtha, K.: What do we know about soil carbon destabilization?, Environ. Res. Lett., 14, 083004, https://doi.org/10.1088/1748-9326/ab2c11, 2019.

Berhe, A. A., Harte, J., Harden, J. W., and Torn, M. S.: The Significance of the Erosion-induced Terrestrial Carbon Sink, BioScience, 57, 337-346, https://doi.org/10.1641/b570408, 2007.

Beuselinck, L., Govers, G., Poesen, J., Degraer, G., and Froyen, L.: Grain-size analysis by laser diffractometry: Comparison with the sieve-pipette method, Catena, 32, 193-208, https://doi.org/10.1016/S0341-8162(98)00051-4, 1998.

Bosatta, E. and Ågren, G. I.: Soil organic matter quality interpreted thermodynamically, Soil Biol. Biochem., 31, 1889-1891, https://doi.org/10.1016/S0038-0717(99)00105-4, 1999.

Brown, A. G., Fallu, D. J., Walsh, K., Cucchiaro, S., Tarolli, P., Zhao, P., Pears, B., Van Oost, K., Snape, L., Lang, A., Albert, R., Alsos, I. G., and Waddington, C.: Ending the cinderella status of terraces and lynchets in Europe: the geomorphology of agricultural terraces and implications for ecosystem services and climate adaptation, Geomorphology, 379, 107579, https://doi.org/10.1016/j.geomorph.2020.107579, 2021.

British Geological Survey, Natural Environment Research Council, Nottingham, available at: https://www.mineralsuk.com (last access: 4 December 2021), 2018.

Chen, D., Wei, W., Daryanto, S., and Tarolli, P.: Does terracing enhance soil organic carbon sequestration? A nationalscale data analysis in China, Sci. Total Environ., 721, 137751, https://doi.org/10.1016/j.scitotenv.2020.137751, 2020. 
Cockcroft, D. and Waddington, C.: Plantation Camp Agricultural Terraces, Northumberland Archaeological Evaluation, unpublished technical report, Archaeological Research Services Ltd., Bakewell, forthcoming, 2020.

Craine, J. M., Fierer, N., and McLauchlan, K. K.: Widespread coupling between the rate and temperature sensitivity of organic matter decay, Nat. Geosci., 3, 854-857, https://doi.org/10.1038/ngeo1009, 2010a.

Craine, J., Spurr, R., McLauchlan, K., and Fierer, N.: Landscapelevel variation in temperature sensitivity of soil organic carbon decomposition, Soil Biol. Biochem., 42, 373-375, https://doi.org/10.1016/j.soilbio.2009.10.024, 2010b.

Cucchiaro, S., Fallu, D. J., Zhang, H., Walsh, K., Van Oost, K., Brown, A. G., and Tarolli, P.: Multiplatform-SfM and TLS Data Fusion for Monitoring Agricultural Terraces in Complex Topographic and Landcover Conditions, Remote Sens.-Basel, 12, 1946, https://doi.org/10.3390/rs12121946, 2020a.

Cucchiaro, S., Fallu, D. J., Zhao, P., Waddington, C., Cockcroft, D., Tarolli, P., and Brown, A. G.: SfM photogrammetry for GeoArchaeology, in: Remote Sensing of Geomorphology, Elsevier B.V., 183-205, https://doi.org/10.1016/B978-0-444-641779.00006-0, 2020b.

Curtaz, F., Stanchi, S., D’Amico, M. E., Filippa, G., Zanini, E., and Freppaz, M.: Soil evolution after land-reshaping in mountains areas (Aosta Valley, NW Italy), Agr. Ecosyst. Environ., 199, 238248, https://doi.org/10.1016/j.agee.2014.09.013, 2015.

Davidson, E. A. and Janssens, I. A.: Temperature sensitivity of soil carbon decomposition and feedbacks to climate change, Nature, 440, 165-173, https://doi.org/10.1038/nature04514, 2006.

De Blécourt, M., Hänsel, V. M., Brumme, R., Corre, M. D., and Veldkamp, E.: Soil redistribution by terracing alleviates soil organic carbon losses caused by forest conversion to rubber plantation, Forest Ecol. Manag., 313, 26-33, https://doi.org/10.1016/j.foreco.2013.10.043, 2014.

Doetterl, S., Cornelis, J.-T., Six, J., Bodé, S., Opfergelt, S., Boeckx, P., and Van Oost, K.: Soil redistribution and weathering controlling the fate of geochemical and physical carbon stabilization mechanisms in soils of an eroding landscape, Biogeosciences, 12, 1357-1371, https://doi.org/10.5194/bg-12-1357-2015, 2015.

Doetterl, S., Berhe, A. A., Nadeu, E., Wang, Z., Sommer, M., and Fiener, P.: Erosion, deposition and soil carbon: A review of process-level controls, experimental tools and models to address C cycling in dynamic landscapes, Earth-Sci. Rev., 154, 102-122, https://doi.org/10.1016/j.earscirev.2015.12.005, 2016.

Doetterl, S., Berhe, A. A., Arnold, C., Bodé, S., Fiener, P., Finke, P., Fuchslueger, L., Griepentrog, M., Harden, J. W., Nadeu, E., Schnecker, J., Six, J., Trumbore, S., Van Oost, K., Vogel, C., and Boeckx, P.: Links among warming, carbon and microbial dynamics mediated by soil mineral weathering, Nat. Geosci., 11, 589593, https://doi.org/10.1038/s41561-018-0168-7, 2018.

Dunjó, G., Pardini, G., and Gispert, M.: Land use change effects on abandoned terraced soils in a Mediterranean catchment, NE Spain, Catena, 52, 23-37, https://doi.org/10.1016/S03418162(02)00148-0, 2003.

Frodsham, P. and Waddington, C.: The Breamish Valley Archaeology Project 1994-2002. Archaeology in Northumberland National Park, Report 136, 171-189, Council for British Archaeology Research, Cambridge, 2004.
Gao, X., Li, W., Salman, A., Wang, R., Du, L., Yao, L., Hu, Y., and Guo, S.: Impact of topsoil removal on soil $\mathrm{CO}_{2}$ emission and temperature sensitivity in Chinese Loess Plateau, Sci. Total Environ., 708, 135102, https://doi.org/10.1016/j.scitotenv.2019.135102, 2020.

Gillabel, J., Cebrian-Lopez, B., Six, J., and Merckx, R.: Experimental evidence for the attenuating effect of SOM protection on temperature sensitivity of SOM decomposition, Glob. Change Biol., 16, 2789-2798, https://doi.org/10.1111/j.13652486.2009.02132.x, 2010.

Harden, J. W., Sharpe, J. M., Parton, W. J., Ojima, D. S., Fries, T. L., Huntington, T. G., and Dabney, S. M.: Dynamic replacement and loss of soil carbon on eroding cropland, Global Biogeochem. Cy., 13, 885-901, https://doi.org/10.1029/1999GB900061, 1999.

Kagabo, D. M., Stroosnijder, L., Visser, S. M., and Moore, D.: Soil erosion, soil fertility and crop yield on slow-forming terraces in the highlands of Buberuka, Rwanda, Soil Till. Res., 128, 23-29, https://doi.org/10.1016/j.still.2012.11.002, 2013.

Kirschbaum, M. U. F.: The temperature dependence of soil organic matter decomposition, and the effect of global warming on soil organic C storage, Soil Biol. Biochem., 27, 753-760, https://doi.org/10.1016/0038-0717(94)00242-S, 1995.

Knorr, W., Prentice, I. C., House, J. I., and Holland, E. A.: Longterm sensitivity of soil carbon turnover to warming, Nature, 433, 298-301, https://doi.org/10.1038/nature03226, 2005.

Kögel-Knabner, I., Guggenberger, G., Kleber, M., Kandeler, E., Kalbitz, K., Scheu, S., Eusterhues, K., and Leinweber, P.: Organo-mineral associations in temperate soils: Integrating biology, mineralogy, and organic matter chemistry, J. Plant Nutr. Soil Sc., 171, 61-82, https://doi.org/10.1002/jpln.200700048, 2008.

Liu, Y., Wang, C., He, N., Wen, X., Gao, Y., Li, S., Niu, S., Butterbach-Bahl, K., Luo, Y., and Yu, G.: A global synthesis of the rate and temperature sensitivity of soil nitrogen mineralization: latitudinal patterns and mechanisms, Glob. Change Biol., 23, 455-464, https://doi.org/10.1111/gcb.13372, 2017.

Mesfin, A.: A Field Guideline on Bench Terrace Design and Construction, available at: https://nrmdblog.files.wordpress. com/2016/04/bench-terrace-manual.pdf (last access: 2 December 2021), Ministry of Agriculture and Natural Resources Natural Resource Management Directorate, Ethiopia, 2016.

Muñoz-Salinas, E., Bishop, P., Sanderson, D. C., and Zamorano, J. J.: Interpreting luminescence data from a portable OSL reader: Three case studies in fluvial settings, Earth Surf. Proc. Land., 36, 651-660, https://doi.org/10.1002/esp.2084, 2011.

Paul, E. A., Morris, S. J., and Bohm, S.: The determination of soil C pool sizes and turnover rates: biophysical fractionation and tracers, Assessment Methods for Soil Carbon, 14, 193-206, 2001.

Porat, N., López, G. I., Lensky, N., Elinson, R., Avni, Y., ElgartSharon, Y., Faershtein, G., and Gadot, Y.: Using portable OSL reader to obtain a time scale for soil accumulation and erosion in archaeological terraces, the Judean Highlands, Israel, Quat. Geochronol., 49, 65-70, 2019.

Portenga, E. W., Bishop, P., Gore, D. B., and Westaway, K. E.: Landscape preservation under post-European settlement alluvium in the south-eastern Australian tablelands, inferred from portable OSL reader data, Earth Surf. Proc. Land., 41, $1697-$ 1707, 2016.

Shi, P., Zhang, Y., Li, P., Li, Z., Yu, K., Ren, Z., Xu, G., Cheng, S., Wang, F., and Ma, Y.: Distribution of soil organic car- 
bon impacted by land-use changes in a hilly watershed of the Loess Plateau, China, Sci. Total Environ., 652, 505-512, https://doi.org/10.1016/j.scitotenv.2018.10.172, 2019.

Six, J., Elliott, E. T., Paustian, K., and Doran, J. W.: Aggregation and Soil Organic Matter Accumulation in Cultivated and Native Grassland Soils, Soil Sci. Soc. Am. J., 62, 1367, https://doi.org/10.2136/sssaj1998.03615995006200050032x, 1998.

Six, J., Conant, R. T., Paul, E. A., and Paustian, K.: Stabilization mechanisms of soil organic matter: Implications for C-saturation of soils, Plant Soil, 241, 155-176, https://doi.org/10.1023/A:1016125726789, 2002.

Sollins, P., Homann, P., and Caldwell, B. A.: Stabilization and destabilization of soil organic matter: Mechanisms and controls, Geoderma, 74, 65-105, https://doi.org/10.1016/S00167061(96)00036-5, 1996.

Stavi, I., Gusarov, Y., and Halbac-Cotoara-Zamfir, R.: Collapse and failure of ancient agricultural stone terraces: On-site geomorphic processes, pedogenic mechanisms, and soil quality, Geoderma, 344, 144-152, https://doi.org/10.1016/j.geoderma.2019.03.007, 2019.

Tarolli, P., Preti, F., and Romano, N.: Terraced landscapes: from an old best practice to a potential hazard for soil degradation due to land abandonment, Anthropocene, 6, 10-25. https://doi.org/10.1016/j.ancene.2014.03.002, 2014.

Tarolli, P., Sofia, G., Calligaro, S., Prosdocimi, M., Preti, F., and Dalla Fontana, G.: Vineyards in Terraced Landscapes: New Opportunities from Lidar Data, Land Degrad. Dev., 26, 92-102, https://doi.org/10.1002/ldr.2311, 2015.

Van Oost, K., Quine, T. A., Govers, G., De Gryze, S., Six, J., Harden, J. W., Ritchie, J. C., McCarty, G. W., Heckrath, G., Kosmas, C., Giraldez, J. V., Marques Da Silva, J. R., and Merckx, R.: The impact of agricultural soil erosion on the global carbon cycle, Science, 318, 626-629, https://doi.org/10.1126/science.1145724, 2007.

Van Oost, K., Verstraeten, G., Doetterl, S., Notebaert, B., Wiaux, F., Broothaerts, N., and Six, J.: Legacy of humaninduced $\mathrm{C}$ erosion and burial on soil-atmosphere C exchange, P. Natl. Acad. Sci. USA, 109, 19492-19497, https://doi.org/10.1073/pnas.1211162109, 2012.
VandenBygaart, A. J., Kroetsch, D., Gregorich, E. G., and Lobb, D.: Soil C erosion and burial in cropland, Glob. Change Biol., 18, 1441-1452, https://doi.org/10.1111/j.1365-2486.2011.02604.x, 2012.

VandenBygaart A. J., Gregorich E. G., and Helgason B. L.: Cropland $\mathrm{C}$ erosion and burial: Is buried soil organic matter biodegradable?, Geoderma, 239, 240-249, https://doi.org/10.1016/j.geoderma.2014.10.011, 2015.

Walter, C., Merot, P., Layer, B., and Dutin, G.: The effect of hedgerows on soil organic carbon storage in hillslopes, Soil Use Manage., 19, 201-207, https://doi.org/10.1079/sum2002190, 2003.

Wang, Q., Liu, S., and Tian, P.: Carbon quality and soil microbial property control the latitudinal pattern in temperature sensitivity of soil microbial respiration across Chinese forest ecosystems, Glob. Change Biol., 24, 2841-2849, https://doi.org/10.1111/gcb.14105, 2018.

Wang, Z., Van Oost, K., Lang, A., Quine, T., Clymans, W., Merckx, R., Notebaert, B., and Govers, G.: The fate of buried organic carbon in colluvial soils: a long-term perspective, Biogeosciences, 11, 873-883, https://doi.org/10.5194/bg-11-873-2014, 2014.

Wang, Z., Van Oost, K., and Govers, G.: Predicting the long-term fate of buried organic carbon in colluvial soils, Global Biogeochem. Cy., 29, 65-79, https://doi.org/10.1002/2014GB004912, 2015.

Wei, W., Chen, D., Wang, L., Daryanto, S., Chen, L., Yu, Y., Lu, Y., Sun, G., and Feng, T.: Global synthesis of the classifications, distributions, benefits and issues of terracing, Earth-Sci. Rev., 159, 388-403, https://doi.org/10.1016/j.earscirev.2016.06.010, 2016.

Wiaux, F., Vanclooster, M., and Van Oost, K.: Vertical partitioning and controlling factors of gradient-based soil carbon dioxide fluxes in two contrasted soil profiles along a loamy hillslope, Biogeosciences, 12, 4637-4649, https://doi.org/10.5194/bg-124637-2015, 2015.

Xia, S., Song, Z., Li, Q., Guo, L., Yu, C., Singh, B. P., Fu, X., Chen, C., Wang, Y., and Wang, H.: Distribution, sources, and decomposition of soil organic matter along a salinity gradient in estuarine wetlands characterized by $\mathrm{C}: \mathrm{N}$ ratio, $\delta^{13} \mathrm{C}-\delta^{15} \mathrm{~N}$, and lignin biomarker, Glob. Change Biol., 27, 417-434, 2021. 